\title{
DINAMIKA ORIENTASI SEKSUAL PADA KAUM GAY
}

\author{
Fathul Hidayah \\ Magister Psikologi, Direktorat Program Pasca Sarjana, Universitas Muhammadiyah Malang, \\ Malang, Jawa Timur, Indonesia
}

\begin{abstract}
There is a different group of people with certain sexual orientations inside a community. Sexual orientation is divided into three namely heterosexual, bisexual, and homosexual. In this study, which trying to lift the topic of the dynamics of gay sexual orientation. Gay is a sexual inclination which men are intereted into fellow men. There is one thing that is most important in the dynamics of gay orientation, it is called the formation of sexual orientation identity. The purpose of this study is to know the full picture of the dynamics of sexual orientation on gays. This research uses qualitative research method with the design of case study about the life history type. Three Respondents are involved in this study, 1 person as the main respondent and 2 people as significant others. The results of this study indicate that there were several causes until the respondent becomes gay, when he was a 6 grader, he imitated the blue film he watched, then disappointed because he was betrayed by his female partner, and because of the environment that encouraged him to go deeper into the gay world.
\end{abstract}

Keywords: Sexual orientation, gay, the dynamics of gay sexual orientation.

\begin{abstract}
ABSTRAK
Didalam masyarakat terdapat sekelompok orang yang memiliki orientasi seksual yang berbeda. Orientasi seksual terbagi menjadi tiga yakni heteroseksual, biseksual, dan homoseksual. Dalam penelitian ini, yang coba diangkat yakni dinamika orientasi seksual pada kaum gay. Gay merupakan suatu kecenderungan seksual dimana laki-laki menyukai sesama laki-laki. Terdapat satu hal yang paling penting dalam dinamika orientasi kaum gay yakni pada pembentukan identitas orientasi seksual. Tujuan penelitian ini adalah untuk mengetahui gambaran secara lengkap tentang dinamika orientasi seksual pada kaum gay. Penelitian ini menggunakan metode penelitian kualitatif dengan desain studi kasus berjenis life history. Responden yang dilibatkan dalam penelitian ini berjumlah 3 orang, 1 orang sebagai responden utama dan 2 orang sebagai significant others. Hasil dari penelitian ini menunjukkan bahwa terdapat beberapa penyebab hingga responden menjadi gay, yakni ketika kelas 6 SD ia melakukan imitasi terhadap blue film yang ia tonton, kemudian adanya kekecewaan karena dihianati oleh pasangan perempuannya, dan karena lingkungan yang mendorongnya untuk terus masuk kedalam dunia gay.
\end{abstract}

Kata kunci: Orientasi seksual, gay, dinamika orientasi seksual kaum gay. 
Psikologia (Jurnal Psikologi), Vol 2 (2), July 2017, 53 -70

ISSN 2338-8595 (print), ISSN 2541-2299 (online) Journal Homepage: http://ojs.umsida.ac.id/index.php/psikologia

DOI Link: 10.21070/psikologia.v3i1.1549

\section{PENDAHULUAN}

Manusia merupakan makhluk sosial, yang mana tidak bisa hidup tanpa bantuan orang lain atau lingkungan. Didalam menjalani setiap fase dalam kehidupan seorang individu terutama yang telah memasuki fase dewasa akan membutuhkan seorang pendamping hidup. Seperti yang digambarkan oleh Maslow pada hirarki kebutuhannya bahwa manusia memiliki kebutuhan akan rasa aman dan cinta (Zakaria \& Malek, 2014). Diaman rasa aman dan cinta bisa didapatkan dari pasangan hidup. Didalam proses untuk mencari pasangan hidup, individu memiliki kecenderungan seksual atau biasa dikenal dengan orientasi seksual (Gonsiorek, 2013; Ngun \& Vilain, 2014). Revisi terbaru dari DSM-5 menyatakan bahwa orientasi seksual ini masuk kedalam "dysphoria gender" (Moleiro \& Pinto, 2015). Penyimpangan seksual ini diartikan sebagai ketidak wajaran seksual (sexual pervesion) mencakup perilaku-perilaku atau fantasi-fantasi seksual yang ditujukan pada pecapaian orgasme melalui relasi seksual. Perilaku menyimpang seksual ini merupakan sebuah relasi heteroseksual yang memiliki sifat kompulsif serta menetap, sehingga dapat dikategorikan kedalam gangguan kepribadian serta merupakan penyakit neurotis (Hayadi \& Manna, 2017).

Orientasi seksual terbagi menjadi tiga bagian, yang pertama adalah heteroseksual yang mana ketertarikan individu terhadap lawan jenis. Kedua adalah ketertarikan secara seksual pada jenis kelamin yang sama, perempuan tertarik pada perempuan yang disebut lesbian, dan laki-laki yang tertarik pada laki-laki disebut gay. Ketiga yakni biseksual, dimana individu memiliki ketertarikan terhadap lawan jenis dan sesama jenis, artinya ketertarikan secara seksual pada perempuan dan laki-laki sekaligus (Mastuti, Winarno, \& Hastuti, 2012).

Saat ini, telah banyak bermunculan fenomena-fenomena terkait dengan LGBT (Lesbian, Gay, Biseksual, Transgender). Meskipun telah banyak bermunculan tetapi sampai saat ini, LGBT masih dianggap menyimpang serta melanggar norma-norma yang ada didalam masyarakat. Msyarakat lebih menerima keadaan seseorang untuk menjadi heteroseksual. Permasalahan kini dihadapi oleh kaum LGBT kususnya di Indonesia yakni mengenai keberadaan kaum LGBT yang masih dirasa asing untuk bisa di terima di lingkungan masyarakat awam. Kenyataannya bahwa sebagian masyarakat 
Psikologia (Jurnal Psikologi), Vol 2 (2), July 2017 , 117 -134

ISSN 2338-8595 (print), ISSN 2541-2299 (online) Journal Homepage: http://ojs.umsida.ac.id/index.php/psikologia

DOI Link: 10.21070/psikologia.v3i1.1549

besar memandang bahwa kaum LGBT adalah simbol kekejian, yakni suatu aib yang memalukan bagi pihak keluarga (Mastuti et al., 2012). Kaum LGBT sering mengalami berbagai bentuk diskriminasi, stigma, dan pengucilan sosial termasuk kekerasan fisik dan psikologis diantaranya yakni bullying dan penganiayaan. Diskriminasidiskriminasi ini dapat terjadi di berbagai lingkungan seperti dalam lingkungan pekerjaan, pendidikan dan bahkan kesehatan (Moleiro \& Pinto, 2015).

Terdapat beberapa dampak negatif yang karna perilaku LGBT, yang pertama yakni dari segi kesehatan, perilaku seks yang dilakukan oleh kaum LGBT beresiko terjangkit virus HIV/AIDS. Yang kedua yakni moralitas, yang mana dalam agama terutama agama islam sangat melarang perilaku tersebut, selain itu norma di masyarakatpun menganggap bahwa perilaku LGBT merupakan perilaku yang tidak baik. Yang ketiga yakni sosial, dimana perilaku gay dan lesbian tidak bisa menghasilkan keturunan, serta mnegkibatkan kerusakan pada keluarga. Jika perilaku tersebut dilegalkan maka di masa yang akan datang akan terjadi kepunahan spesies. Dan yang ke empat yakni keamanan, didalam komunitas LGBT sering terjadi kekerasan seksual bahkan pembunuhan. Hal tersebut terjadi dikarenakan perilaku kaum LGBT yang mudah berganti pasangan, memiliki kecenderungan pemaksaan kehendak, dominan terhadap pasangan sejenis, kesenangan membabibuta, atau sebaliknya yakni kecewa berat yang berujung pembunuhan (Yudiyanto, 2016).

Salah satu bagian dari LGBT yang sangat menarik untuk dilihat yakni homoseksual. Dimana secara bahasa homoseksual berasal dari kata Yunani yakni homo yang memiliki arti "sama". Homoseksual merupakan ketertarikan seksual individu terhadap sesama jenis baik laki-laki maupun perempuan (Patterson, 2000., Feldmen, 1990). Individu yang mengalami homoseksual tidak hanya melakukan kontak seksual sengan sesama jenis kelamin, tetapi juga memiliki kecenderungan sisi psikologis, emosional, dan sosial (Kendal \& Hammen, 1998). Homoseksual dibagi menjadi dua jenis, yakni gay dan lesbian.

Homoseksual dapat disebabkan karena beberapa hal, menurut pendekatan biologi, menggambarkan bahwa homoseksual disebabkan oleh faktor genetik atau hormon (Ngun \& Vilain, 2014). Menurut pendekatan psikoanalis memberikan gambaran bahwa 
Psikologia (Jurnal Psikologi), Vol 2 (2), July 2017 , 117 -134

ISSN 2338-8595 (print), ISSN 2541-2299 (online) Journal Homepage: http://ojs.umsida.ac.id/index.php/psikologia

DOI Link: 10.21070/psikologia.v3i1.1549

pengaruh ibu terhadap individu lebih dominan sedangkan ayah cenderung pasif. Sedangkan menurut pendekadan behavioris, homoseksual disebabkan karna proses belajar (Feldman, 1990).

Terdapat tiga kriteria dalam menentukan bahwa individu homoseksual (Kendall \& Hammen, 1998), diantaranya yaitu mimiliki ketertarikan secara seksual terhadap individu yang memiliki kesamaan gander dengan dirinya. Kedua, keterlibatan secara seksual sengan satu individu atau lebih yang memiliki kesamaan gander dengan dirinya. Dan ketiga, mengidentifikasi atau memandang dirinya sebagai gay atau lesbian.

Gay merupakan individu laki-laki yang menyukai sesama jenis kelamin (Hening \& Fridari, 2014). Berdasarkan penelitian yang pernah dilakukan. Para ahli dan PBB menggambarkan bahwa peningkatan gay dari tahun 2010 sampai 2012 diperkirakan dari 800.000 menjadi 3.000 .000 orang. Di indonesia jumlah gay pada tahun 2016 sebanyak 20.000 orang yang mana diwilayah Jakarta diperkirakan terdapat sekitar 5.000 gay dan di profinsi Jawa Timur sendiri diperkirakan sebanyak 348.000 gay dari 6.000.000 penduduk Jawa Timur (Yudiyanto, 2016).
Dalam dinamika orientasi seksual kaum gay sendiri terdapat bagian yang sangat penting yakni pembentukan identitas orientasi seksual pada kaum gay. pembentukan identitas pada kaum gay sendiri memiliki 6 tahapan yakni identity confusion (kebingungan), identity comparison (membandingkan), identity telerance (yakin), identity acceptance (membuka jati diri), identity pride (bangga), dan identity synthesis (merasa nyaman) (Mastuti et al., 2012). Pembentukan identitas ini tidak selalu terjadi secara teratur, dan biasanya juga tidak terjadi secara tiba-tiba.

Kaum gay rentan terhadap resiko bunuh diri, reaksi stress traumatik, gangguan depresi besar, penyalah gunaan narkoba, gangguan kecemasan umum, fobia sosial dan gangguan makan. Namun hal-hal tersebut dapat dimediasi oleh beberapa variabel, termasuk diantaranya ykani dukungan sosial dan keluarga, kontak dengan kaum atau komunitas gay yang lain, serta religiusitas (Moleiro \& Pinto, 2015). Komunitas gay densiri dapat memberikan dukungan sosial untuk mengembalikan kepercayaan diri dan harga diri kaum gay. Komunitas gay menjadi bagian yang penting dalam kehidupan gay karna dapat berfungsu dalam menjada rahasia dan juga sebagai 
Psikologia (Jurnal Psikologi), Vol 2 (2), July 2017 , 117 -134

ISSN 2338-8595 (print), ISSN 2541-2299 (online) Journal Homepage: http://ojs.umsida.ac.id/index.php/psikologia

DOI Link: 10.21070/psikologia.v3i1.1549

pelindung. Dukungan sosial yang bersumber dari komunitas ini dapat memberikan informasi terkait hal apa yang harus dilakukan dalam hal upaya membentuk identitas dirinya, selain itu dapat pula memberikan timbal balik atas apa yang dilakukan dalam kelompok dan lingkungan sosialnya, serta mmberikan kesempatan untuk mencoba berbagai macam peran dalam menyelesaikan permasalahan guna membentuk identitas diri yang optimal (Mastuti et al., 2012).

Dengan berbagai uraian diatas maka banyak hal yang sangat menarik untuk diteliti terkait dinamika orientasi seksual pada kaum gay. Fokus dari penelitian ini terletak pada gambaran dinamika orientasi seksual pada kaum gay. Dimana dinamika yang akan di gambarkan dalam penelitian ini yakni gambaran terkait masa kecil kaum gay, gabaran awal mula memiliki ketertarikan kepada sesama jenis, hal-hal yang menyebabkan ketertarikan kepada lawan jenis, gambaran responden menjadi gay, hubungan interpersonal kaum gay, dan hubungan seksualitas kaum gay. Tujuan dalam penelitian ini sendiri yakni dimana peneliti ingin mengetahui terkait dinamika orientasi seksual pada kaum gay.

\section{METODE PENELITIAN}

Metode yang digunakan dalam penelitian ini yakni metode penelitian kualitatif. Dimana metode penelitian kualitatif adalah penelitian yang bermaksud untuk memahami fenomena tentang apa yang dialami oleh subjek penelitian misalnya perilaku, persepsi, motivasi, tindakan, dll, secara holistik dan dengan cara deskripsi dalam bentuk kata-kata dan bahasa, pada suatu konteks khusus yang alamiah dan dengan memanfaatkan berbagai metode alamiah (Lexy \& Moleong, 2014). Penelitian ini menggunakan desain penelitian studi kasus dengan jenis studi kasus yakni life history. Life history ini digunanakan guna untuk mendapatkan pemahaman, pengertian dan infomasi yang mendalam terkait masalah, situasi, dan makna suatu objek yang diteliti dengan cara mencari tau secara lengkap terkait biografi subjek dan pengalaman-pengalaman dimasa lampau hingga saat ini yang menyebabkan munculnya perilaku-perilaku saat ini (Creswell, 2014).

Penelitian ini akan dilakukan di daerah kabupaten malang, dimana merupakan tempat peneliti menemukan fenomena kaum gay. Tempat penelitian sendiri akan dilakukan di tempat yang direkomendasikan 
Psikologia (Jurnal Psikologi), Vol 2 (2), July 2017 , 117 -134

ISSN 2338-8595 (print), ISSN 2541-2299 (online) Journal Homepage: http://ojs.umsida.ac.id/index.php/psikologia

DOI Link: 10.21070/psikologia.v3i1.1549

oleh responden dengan tujuan kenyamanan dan kerahasiaan responden mengingat fenomena penelitian cukup sensitif.

Satuan Kajian dalam penelitian ini menggunakan sampel perseorangan atau idividual yakni menggunakan hanya satu responden. Yakni individu yang memiliki kecenderungan menyukai sesama jenis. Untuk mendapatkan sumber data maka peneliti melakukan entry perencanaan dalam mendapatkan partisipan penelitian. Dalam melakukan entry penelitian ini, pertama peneliti melihat fenomena kaum gay di wilayah malang, kemudian peneliti memutuskan untuk meneliti kaum gay, selanjutnya peneliti melihat kembali fenomena-fenomena yang dialami kaum gay, dari sini peneliti kemudian memutuskan untuk memilih dinamika orientasi seksual sebagai topik penelitian. Kemudian peneliti mencari subjek yang sesuai dengan kriterian penelitian. Adapun keriterian dalam menentukan responden yakni yang pertama memiliki kecenderungan menyukai sesama jenis dengan spesifikasi gay, usia memasuki tahap dewasa sehingga dapat menggambarkan dan menjawab pertanyaanpertanyaan penelitian dengan jelas.

Sumber data utama dari penelitian ini yakni seorang individu laki-laki yang merupakan kaum gay yang berdomisili di wilayah Malang. Selain itu, untuk sumber data pendukung yakni dari significant others yang merupakan teman dekat responden. Data dari penelitian ini adalah deskripsi dari dinamika orientasi seksual pada kaum gay. Deskripsi ini diperoleh dari hasil wawancara mendalam yang terfokus, dokumentasi, dan pemeriksaan keabsahan data dengan teknik triangulasi data menggunakan informasi yang diperoleh dari significant others yang mengetahui dinamika kehidupan dari responden. Data yang dikumpulkan yakni dokumentasi berupa deskripsi hasil wawancara peneliti dengan responden dan bukti informasi dari significant others responden berupa diskripsi hasil wawancara.

Alat yang dipakai dalam memperoleh data pada penelitian ini yakni dengan wawancara mendalam (in-depth interview) yang dilakukan terhadap subjek dan significant others. Tahapan pada wawancara mendalam ini pertama digunakan untuk mencari responden penelitian dengan strategi rekomendasi teman yang terpercaya. Selanjutnya setelah mendapatkan rekomendasi responden, maka peneliti menanyakan kesediaan responden untuk menjadi responden penelitian. Setelah responden bersedia maka kemudain peneliti 
Psikologia (Jurnal Psikologi), Vol 2 (2), July 2017 , 117 -134

ISSN 2338-8595 (print), ISSN 2541-2299 (online) Journal Homepage: http://ojs.umsida.ac.id/index.php/psikologia

DOI Link: 10.21070/psikologia.v3i1.1549

melakukan pengenalan dan membangun rapport. Selanjutnya peneliti melakukan wawancara dengan waktu dan tempat sesuai dengan rekomendasi responden mengingat kesensitifitasnya permasalahan ini. Pelaksanaan wawancara ini menggunakan pedoman wawancara yang telah penelii susun.

Adapun tahapan-tahapan dalam analisis data pada penelitian ini. Secara rinci tahaptahap analisis penelitian studi kasus adalah sebagai berikut (Hediansyah, 2015) :

- Organisasi Data.

Peneliti mengolah dan menganalisis data penelitian dengan mengrganisasikan data dengan rapi, sistematis, dan lengkap. Dalam mengorganisasikan data penelitian, peneliti melalui beberapa proses yakni sebagai berikut:

1) Data mentah (catatan lapangan, kaset tape recorder)

2) Data yang sudah diverbatimkan dalam transkrip wawancara

3) Data yang sudah ditandai kode-kode spesifik

4) Penjabaran kode-kode dalam pemadatan fakta
5) Episode analisis (dokumentasi umum yang kronologis mengenai pengumpulan data dan analisis data)

6) Teks laporan (draft yang terus menerus ditambah dan diperbaiki)

Data-data yang diorganisasikan tersebut kemudia peneliti kumpulkan untuk kelengkapan arsip, mulai dari data yang sangat mentah (catatan lapangan dan kaset tape recorder) sampai data yang telah diolah (draft laporan).

- Koding.

Pada tahap koding ini peneliti memberikan kode-kode pada data yang tadi telah diorganisasikan dari data mentah. koding ini sendiri bertujuan untuk dapat lebih mengorganisasi dan mensistematisasi data secara lengkap sehingga data akan memunculkan gambaran dan makna yang jelas terkait dinamika psikologi orientasi seksual kaum gay. Proses koding ini diawali dengan memberikan kode pada data pada transkrip wawancara, kemudian peneliti menyeleksi data dengan memberikan tanda pada transkrip wawancara, kemudian peneliti memindahkan data yang telah 
Psikologia (Jurnal Psikologi), Vol 2 (2), July 2017 , 117 -134

ISSN 2338-8595 (print), ISSN 2541-2299 (online) Journal Homepage: http://ojs.umsida.ac.id/index.php/psikologia

DOI Link: 10.21070/psikologia.v3i1.1549

ditandai ke tabel pemadatan fakta dan analisis awal. Dan yang terakhir peneliti memberikan interpretasi awal dari data-data yang telah diperoleh tersebut.

\section{- Analisis dan Interpretasi Data}

Untuk menganalisis data yang telah diperoleh, peneliti menggunakan analisis tematik, dimana analisis ini dapat digunakan pada hampir semua metode kualitatif dan memungkinkan penerjemahan gejala/informasi kualitatif menjadi data kualitatif seperlu kebutuhan peneliti (Poerwandari, 2005). Untuk melihat keabsahan data, peneliti menggunakan tiga kriteria keabsahan data, yang pertama yakni keabsahan konstruk (construct validity), keabsahan ini dapat dilakukan dengan menggunakan triangulasi data. Yang ke dua yakni keabsahan internal (internal validity), dalam tahap ini peneliti menggunakan 2 tahap inteperetasi yakni yang pertama pemahaman diri (selfunderstanding), yakni interpretasi yang mengacu pada pemahaman diri subjek penelitian divalidasi dalam kerangka subjek penelitian. Yang kedua yakni konteks interpretasi pemahaman teoritis, yang mana pada tingkat pemahaman teoretis ini, peneliti melihat apakah teori yang dipakai cocok untuk bidang yang dipelajari. Kriteria yang terakhir adalah keabsahan eksternal (external validity), keabsahan eksternal ini mengacu pada seberapa jauh hasil penelitian dapat digeneralisasikan pada kasus lain.

Selain itu untuk memeriksa keabsahan data peneliti akan berkomunikasi dengan dosen pembimbing, teman sejawat yang saat ini menempuh pendidikan $S 2$, atau dapat juga berdikusi dengan seseorang yang ahli dalam bidang yang sejenis.

\section{HASIL PENELITIAN}

Hasil dari penelitian ini akan diuraikan secara satu-persatu terkait dinamika orientasi seksual responden.

Responden: Riza

Riza merupakan seorang gay. Awal mula ia menjadi gay berawal dari ketika masa kecil. Ketika kecil, Ariza lebih dekat dengan ibunya, ia cenderung membenci ayahnya dikarenakan ayahnya sering marah dan memukulnya. Pada saat SD ia memiliki seorang sahabat laki-laki yang slalu bersamanya bernama Windi. Dikarenakan seringnya mereka bersama hingga ibu Ariza pernah berkata "kamu jangan terus-terusan pacaran dengan Windi”, tetapi disitu Riza tidak menanggapi dan menganggap itu hanya sebuah lelucon saja. Ketika 
Psikologia (Jurnal Psikologi), Vol 2 (2), July 2017 , 117 -134

ISSN 2338-8595 (print), ISSN 2541-2299 (online) Journal Homepage: http://ojs.umsida.ac.id/index.php/psikologia

DOI Link: 10.21070/psikologia.v3i1.1549

menginjak kelas 6 SD ia bersama kelima teman laki-lakinya menonton blue film bersama-sama, setelah mereka menonton film tersebut kemudian mereka mempraktikkannya antar teman yang menonton.

Ketika menginjak masa SMP, Riza mulai merasa jika laki-laki menarik, tetapi disitu ia masih mencoba mengelak bahwa ia mulai menyukai sesama jenis. Menginjak SMA ia memiliki seorang pacar yang kemudian bertahan selama 8 tahun. Ketika hendak melangkah ke jenjang pernikahan, Riza mendapatkan informasi bahwa pacarnya tersebut pernah tidur dengan sahabatnya, informasi yang Riza terima kemudian ia konfirmasi kepada banyak pihak termasuk pacarnya. Dan setelah ia mencari tau ke banyak pihak, ternyata kabar tersebut benar adanya, disitu ia sangat kecewa dan terguncang. Efek dari kekecewaan tersebut mempengaruhi kesehatan dan pola pikirnya, dimana setelah ia mengetahui hal tersebut kesehatan Riza cenderung menurun hingga masuk rumah sakit, selain itu dampak psikologis yang terjadi padanya yakni ia memiliki pemikiran bahwa perempuan itu tidak baik.

Ketika sedang dalam masa-masa terpuruk, saudara laki-laki Riza masuk dan membuat Riza nyaman. Ketika sedang berada di rumah sakit tiba-tiba saudara Riza menyiumnya untuk pertama kali, ketika itu Riza merasakan bahwa hal tersebut membuatnya nyaman dan bahagia, sehingga semenjak saat itu ia terus tertarik kepada laki-laki. Awal Riza berpacaran dengan lakilaki yakni ketika ia akan berangkan ke Malang. Ia bertemu dengan teman dari teman yang mengantar Riza ke bandara, yang ternyata adalah seorang gay.

Setelah sampai di Malang, Riza tinggal di lingkungan kos yang mendukung dia untuk terus menyukai sesama jenis karna terdapat seseorang yang juga gay. Riza merasa bahwa hidupnya rusak semenjak saat itu, karna ia tidak bisa lepas dan terus berhubungan dengan orang-orang yang juga penyuka sesama jenis. Setelah berpacaran dengan beberapa laki-laki, kemudian ia memutuskan untuk kembali mencoba berpacaran dengan perempuan karna ia merasa ingin mencoba memperbaiki diri, tetapi ketika telah berjalan sekitar beberapa bulan Riza kembali dikecewakan oleh pacarnya tersebut, sikap pacarnya berubah menjadi lebih kasar. Tetapi dari situ pola pikir Riza berubah dari yang awalnya menganggap bahwa perempuan itu buruk, menjadi bahwa tidak semua perempuan itu 
Psikologia (Jurnal Psikologi), Vol 2 (2), July 2017 , 117 -134

ISSN 2338-8595 (print), ISSN 2541-2299 (online) Journal Homepage: http://ojs.umsida.ac.id/index.php/psikologia

DOI Link: 10.21070/psikologia.v3i1.1549

buruk tetapi juga ada yang baik, intinya masing-masing orang itu tidak sama sehinggak tidak bisa disama ratakan.

Meskipun Riza kemudian memiliki pemikiran demikan, ia kemudian memutuskan untuk kembali menjalin hubungan dengan laki-laki karna ia lebih nyaman dengan hal tersebut. Dari situ Riza kemudian masuk lebih dalam lagi ke dunia gay. Bukan hanya memiliki pasangan tetapi ia juga melayani jika ada yang ingin berhubungan badan dengannya. Menurut keterangan Riza, ia telah berhubungan dengan 69 orang tetapi untuk berhubungan badannya ia tidak tau berapa banyak dikarenakan untuk 1 orang saja terkadang mereka berhubungan lebih dari sekali.

Dalam hubungan, Riza bisa melakukan dua peran sekaligus, ini suatu hal yang tidak umum dikarenakan biasanya gay hanya memiliki satu peran. Riza bisa melakukan dua peran yakni top dan bottom tergantung peran pasangan yang ia layani. Tetpi untuk tingkat kenyamanannya, ketika berhubungan seksual Riza lebih nyaman ketika ia berperan menjadi top, tetapi ketika menjalin hubungan yang biasa seperti jalan dan kehidupan sehari-hari ia lebih suka untuk menjadi bottom, dikarenakan jika ia menjadi bottom, ia merasa diperhatikan dan semua kebutuhannya akan dipenuhi oleh pasangan.

Untuk saat ini Riza memiliki pasangan yang bekerja di salah satu rumah sakit yang ada di Malang, hubungan mereka saat ini berjalan dengan baik seperti saling membantu ketika membutuhkan, ketikka pasangan sedih pasangan juga ikut meresakan, ketika pasangan ada masalah saling membantu dan lain sebagaiya meskipun juga tidak luput dari berbagai permasalahan yang timbul. Permasalahanpermasalahan terjadi biasanya timbul karna masalah orang ketiga yakni ketika salah satu dari mereka chating dengan mantan kekasihnya maka itu akan menimbulkan sebuah pertengkaran. Mereka menyelesaikan pertengkarannya dengan cara yang berbeda dengan pasangan pada umumnya, mereka cenderuuung diam dan ketika mereka sudah sama-sama capek dan lapar kemudian mereka berbaikan.

Meskipun saat ini Riza memiliki hubungan dengan seseorang tetapi disisi lain ia juga masih melayani orang secara sembunyi-sembunyi di belakang pasangannya. Alasannya adalah ia membutuhkan uang untuk membiayai kehidupannya di Malang. Meskipun terkadang ia mendapatkan uang dari 
Psikologia (Jurnal Psikologi), Vol 2 (2), July 2017 , 117 -134

ISSN 2338-8595 (print), ISSN 2541-2299 (online) Journal Homepage: http://ojs.umsida.ac.id/index.php/psikologia

DOI Link: 10.21070/psikologia.v3i1.1549

pasangannya, tetapi ia masih merasa kurang untuk memenuhi kebutuhannya tersebut. Tujuan Riza berhubungan dengan orang lain adalah karna uang tetapi disisi lain ia juga menikmati ketika sedang berhubungan badan dengan orang tersebut.

Harapan kedepan yang diingin kan oleh Riza adalah ia ingin berubah dan menjalani hidup normal, artinya ia ingin memiliki pasangan perempuan dan akan setia dengan perempuan tersebut. Prinsipnya ketika ia ingin berhubungan dengan perempuan maka ia harus terlebih dulu memperbaiki diri sendiri, dari segi perilaku dan religiusitas, serta ia juga harus sudah memiliki pekerjaan yang baik untuk menafkahi kehidupan perempuan pilihannya tersebut. Tetapi disini, Riza juga memiliki pemikiran jika ada laki-laki yang mau menikahinya dan membawanya ke luar negri maka ia akan mau melakukannya.

\section{Significant others 1: Nadia}

Nadia pertama kali bertemu dengan Riza yakni ketika permaba, saat itu mereka hanya kenal sekilas saja, mereka mulai dekatt ketika sudah sekelas dan mulai pertengahan perkuliahan. Nadia mulai curiga dengan sikap Riza karna menurut Nadia ia cucok rempong, artinya cucok karna tidak semaco laki-laki lainnya, dan rempong karna paling heboh dibanding yang lain dlam hal menggosip. Tetapi pertama kali tau jika Riza gay yakni dari cerita Riza sendiri. Saat ini, yang mengetahui jika Riza gay hanyalah teman dekatnya saja, keluarga Riza sepertinya belum mengetahui. Tetapi Nadia pernah ditanya oleh salah satu teman yang juga merupakan tetangga Riza di Kalimantan, ia bertanya bagaimana Riza saat ini keadaannya, karna di kampung banyak yang membicarakan Riza.

Penyebab Riza memiliki orientasi seksual gay berawal ketika ia disakiti oleh pacar perempuannya hingga Riza memiliki pemikiran bahwa dia nggak percaya lagi dengan namanya perempuan. Setelah itu, ia dicium oleh saudaranya. Kemudian Riza pindah ke Malang. Di Malang ia menemukan banyak teman yang sama dengan dia, sehingga Riza terus-terusan melakukan perilaku tersebut karna juga didukung oleh teman-temannya tersebut. Setelah ia berpacaran dengan beberapa lakilaki ia kemudian sempat berpacaran dengan seorang perempuan. Menurut Nadia perempuan tersebut freak dalam artinya gaya berpakaiannya tidak bagus. Setelah putus dengan perempuan tersebut, Riza berpacaran kembali dengan laki-laki. 
Psikologia (Jurnal Psikologi), Vol 2 (2), July 2017 , 117 -134

ISSN 2338-8595 (print), ISSN 2541-2299 (online) Journal Homepage: http://ojs.umsida.ac.id/index.php/psikologia

DOI Link: 10.21070/psikologia.v3i1.1549

Nadia hanya tau 2 orang yang pernah pacaran dengan Riza. Yang pertama yakni seorang pramugara yang tampan. Dan yang ke dua yang sekarang. untuk pasangan Riza yang sekarang Nadia belum mengenal lebih jauh hanya pernah bertemu sekali ketika momen wisuda. Suatu ketika Riza pernah bercerita bahwa ia menyesali semua perbuatannya, ia merasa dunia sudah mau kiamat dan dia akan meninggal. Disitu Riza bercerita hingga menangis, dan Nadia mengatakan bahwa "Ri, nggak ada yang nggak mungkin". Tetapi setelah itu besoknya Riza kembali seperti sebelumnya.

Riza ternyata bukan hanya gay tetapi termasuk biseksual yang mana ia juga dapat menyukai perempuan, Riza pernah bercerita bahwa ia juga melayani tante-tante untuk mendapatkan uang. Tetapi meski ia juga dapat menyukai perempuan, untuk saat ini ia lebih dominan menyukai laki-laki, karna menurutnya jika ia ingin menyukai atau berssama dengan perempuan, maka ia harus memperbaiki terlebih dahulu perilaku dan hidupnya.

\section{Peran Riza dengan pasangannya} menurut Nadia ia lebih condong menjadi perempuan karna Riza lebih banyak dan lebih suka dimanjakan. Dan untuk orientasi hidupnya saat ini menurut Nadia, Riza masih having fun dengan hidupnya arinya ia masih dalam zona nyamannya dengan kehidupannya saat ini, ia tidak mau keluar dari zona nyamannya dan terus mengikuti alur kehidupan ibarat seperti air mengalir selalu mengikuti jalur yang ada, tidak berusaha untuk keluar. Harapan Nadia kedepannya agar Riza keembali belajar mencintai wanita karna yang bisa memberi keturunan dan memberi cinta yang sesungguhnya adalah ketika ia memutuskan untuk berpasangan dan mencintai wanita.

Significant others 2: Fiva

Ketika masa kecil, Riza lebih dekat dengan ibunya selain itu ketik SD ia pernah menonton blue film dan setelah menonton blue film tersebut ia mempraktikkannya dengan berciuman bersama teman lakilakinya. Hal tersebut adalah awal dari Riza mulai tertarik dengan laki-laki. Menginjak SMA ia pernah berpacaran dengan perempuan bernama Dara, yang mana mereka berpacaran selama kurang lebih 8 tahun. Mereka sudah merencanakan akan menikah, tetapi ketika sudha dekat hari pernikahan mereka, Reza mendapat informasi bahwa pacarnya tersebut pernah berhubungan badan dengan laki-laki lain. Dari situ kemudian Reza memutuskan untuk mengakhiri hubungannya. Ia sangat kecewa 
Psikologia (Jurnal Psikologi), Vol 2 (2), July 2017 , 117 -134

ISSN 2338-8595 (print), ISSN 2541-2299 (online) Journal Homepage: http://ojs.umsida.ac.id/index.php/psikologia

DOI Link: 10.21070/psikologia.v3i1.1549

dengan kejadian tersebut, kekecewaannya mengakibatkan ia tidak mau lagi berhubungan dengan perempuan.

Kekecewaan yang dialami Riza berpengaruh pada kesehatannya, Riza sempat masuk ke rumah sakit karna sakit setelah putus dengan pacarnya tersebut, ketika di rumah sakit ia dicium oleh pamannya, disitu ia merasa nyaman dan senang. Kemudan setelah itu Riza pergi ke Malang untuk kuliah. Pertama ketemu dengan Riza, Fiva tidak mengira jika Riza adalah seorang gay, karna ia lebih banyak cerita mengenai mantannya yang bernama Dara, hingga suatu ketika, Fifa mengantar Riza pergi ke kos temannya untuk mengambil barang, dan disana teman Riza tidak sengaja mengucapkan terkait pacar laki-laki Riza, dan dari situ kemudian Riza mengakui bahwa ia adalah seorang gay. Fiva sempat shok dengan pernyataan Riza, tetpi seiring berjalannya waktu ia kemudian mengerti, memahami dan mendukung apa yyang terbaik untuk Riza.

Menurut Fiva riza orang yang baik, ia memiliki hubungan bai dengan semua orang termasuk dengan keluarganya. Riza sangat menyayangi keluarganya, begitu dekatnya ia dengan keluarganya, ketika di rumah ada masalah ibunya selalu cerita dan meminta solusi kepada Riza. Mera jua berkomunikasi setiap hari, dan teman-teman Riza, termasuk Fiva juga sering berkomunikasi dengan ibunya. Tetapi hingga saat ini keluarganya belum mengetahui jika Riza adalah gay, mereka masih menganggap bahwa Riza normal. Mungkin jika keluarganya mengetahui, keluarganya akan kecewa dengan perilaku Riza.

Riza sempat memiliki seorang pacar perempuan tetapi Fiva tidak pernah setuju dengan perempuan tersebut karna baginya perempuan tersebut sangat kasar dari segi verbal. Perempuan itu sering memaki-maki Riza dengan kata-kata yang tidak pantas untuk diucapkan. Dengan perlakuan yang terus-menerus itu akhirnya Riza pun memutuskan hubungannya dengan perempuan itu dan kembali berpacaran dengan laki-laki. Riza penah berpacaran dengan seorang pramugara, tetapi mereka putus karna orang ketiga, dan kemudian saat ini berpacaran kembali dengan seorang manager di salah satu rumah sakit yang ada di malang. Fiva pernah bertemu hanya sekali dengan pacar Riza ketika momen wisuda, hal itu dikarenakan pacar Riza saat ini cenderung pendiam.

Harapan kedepannya untuk Riza yakni agar Riza dapat terus bahagia serta bisa lebih 
Psikologia (Jurnal Psikologi), Vol 2 (2), July 2017 , 117 -134

ISSN 2338-8595 (print), ISSN 2541-2299 (online) Journal Homepage: http://ojs.umsida.ac.id/index.php/psikologia

DOI Link: 10.21070/psikologia.v3i1.1549

memperbaiki diri. Bisa kembali berpasangan dengan perempuan, tetapi jika mmemang tidak Fiva berharap apa yang ia pilih akan dapat memberinya keebahagiaan.

\section{PEMBAHASAN}

Dari hasil yang telah diperoleh maka peneliti kemuadian dapat merumuskan sebuah pola dinamika orientasi seksual pada kaum gay. Adanya perilaku gay responden diawali karna adanya pola pengasuhan yang salah di dalam keluarganya, disini responden lebih dekat dengan ibu dibandingkan dengan ayahnya bahkan ia cenderung tidak menyukai ayahnya. Albert Bandura menggambarkan bahwa apa yang dipikirkan akan mempengaruhi peilaku, dan perilaku yang dimunculkan akan menimbulakan reaksi dari orang lain. Hal ini merupakan suatu gambaran ketika orang tua memberikan pola asuh, pemikiran, dan kondisi lingkungan keluarga yang buruk terhadap anak, maka anak akan cenderung berperilaku maladaptif (Bandura, 1971) .

Selain pola asuh, adanya imitasi yang dilakukan oleh reponden dan teman temannya setelah menonton blue film juga berpengaruh. Peran imitasi (modeling) dalam pembelajaran termasuk kedalam fokus teori pembelajaran sosial kognitif.
Teori ini menggambarkan sebagian besar dari apa yang kita pelajari didasarkan pada pengamatan perilaku orang lain, bukan pengalaman langsung dan penguatan. (Glassman \& Hadad, 2009). Paparan dari perilaku yang ada pada blue film dan pemraktikkan yang salah yang dilakukan oleh rekponden dan teman-t emannya kemungkinan besar akan meningkatkan potensi perilaku maladaptif pada pengamat.

Freud menggambarkan bahwa dasar kepribadian seorang individu diperoleh sejak pada masa kanak-kanak. Kejadian-kejadian pada masa ia anak-anak, akan menjadi bagian dari ketidak sadaran. Selanjutnya, pengalaman di masa mendatang merupakan sebuah pengulangan dari pengalaman masa lalu. Sehingga ketika masa anak-anak, individu mendapatkan pola asuh yang buruk dari orang tua, seperti seringnya dihukum, dimarahi, dan melihat orang tuanya bertengkar, serta memiliki pengalamanpengalaman yang tidak wajar maka pada tahap perkembangan selanjutnya, individu akan dapat berperilaku seperti orang tua mereka ataupun berperilaku seperti pengalaman-pengalaman yang telah mereka alami sebagai bentuk pengulangan dari pengalaman masa lalu. 
Psikologia (Jurnal Psikologi), Vol 2 (2), July 2017 , 117 -134

ISSN 2338-8595 (print), ISSN 2541-2299 (online) Journal Homepage: http://ojs.umsida.ac.id/index.php/psikologia

DOI Link: 10.21070/psikologia.v3i1.1549

Selanjutnya adanya traumatik yang dialami oleh responden akibat adanya kekecewaan yang ia alami kepada perempuan. Dampak dari traumatik seseorang bermacam-macam, dari mulai perubahan pola pikir, perubahan perilaku, perubahan dari segi kesehatan dan lain sebagainya. Selain itu adanya pengalaman baru yang menjadi titik berat penyebab responden menjadi gay, yakni ketika dalam kondisi yang terpuruk, saudara laki-laki responden datang dan membuat responden nyaman dengan perhatian dan kasih sayangnya. Dampak dari kekecewaan dan pengalaman setelah dikecewakan responden ini sendiri lebih berpengaruh besar kepada pola pikirnya, responden menganggap bahwa perempuan itu adalah mahluk yang buruk dan ia merasakan adanya kenyamanan dan kebahagiaan ketika diperhatikan oleh seorang laki-laki. Pada teori kognitif merujuk pada dua cara proses mental yang dapat mempengaruhi perilaku, yang pertama yakni individu belajar dengan mengamati apa yang dilakukan orang lain, dan yang kedua yakni pikiran dan persepsi kita secara tidak langsung dapat mempengaruhi perilaku (Glassman \& Hadad, 2009). Artinya ketika pemikiran dan persepsi responden akan perempuan itu buruk maka akan berdampak pada perilakunya, yang mana ia tidak mau lagi untuk menjalin hubungan dengan perempuan.

Dengan adanya pemikiran yang salah ini, setelah responden pindah ke Malang, ia berada di lingkungan yang sangat mendukung dia untuk terus berperilaku menyukai laki-laki dan berpikir bahwa lakilaki itu lebih menarik dan lebih baik dibandingkan perempuan. Keadaan atau kondisi lingkungan akan mempengaruhi perilaku individu. Keadaan lingkungan akan menimbulkan reaksi-reaksi tersendiri dari individu, yang mana dapat memberikan stimulus terhadap individu untuk melakukan sesuatu berdasarkan apa yang mereka lihat, cermati, dalam lingkungan tersebut (Bandura, 1971). Artinya ketika lingkungan individu itu positif akan mengarahkan individu ke hal yang positif pula meskipun individu memiliki pengalam-pengalaman dan pola pikir yang buruk. Tetapi ketika lingkungan individu itu negatif dan sejalan dengan apa yang dialami individu maka kemungkinan besar individu itu akan terus mengikuti pola pikirnya yang negatif dan pastinya berdampak pada perilakunya yang negatif pula.

Pada dinamika orientasi seksual kaum gay sendiri terdapat bagian yang sangat 
Psikologia (Jurnal Psikologi), Vol 2 (2), July 2017 , 117 -134

ISSN 2338-8595 (print), ISSN 2541-2299 (online) Journal Homepage: http://ojs.umsida.ac.id/index.php/psikologia

DOI Link: 10.21070/psikologia.v3i1.1549

penting yakni pembentukan identitas orientasi seksual pada kaum gay. pembentukan identitas pada kaum gay sendiri memiliki 6 tahapan yakni identity confusion (kebingungan), identity comparison (membandingkan), identity telerance (yakin), identity acceptance (membuka jati diri), identity pride (bangga), dan identity synthesis (merasa nyaman) (Mastuti et al., 2012).

Yang pertama, pada tahap identity confusion, responden mengalami kebingungan ketika masa SMP, yang mana ia merasa jika laki-laki itu menarik, tetapi disini, responden kemudian mencoba menghidar dan mengelak dengan cara memiliki dan menyukai seorang pacar perempuan. Tahap yang kedua yakni identity comparison, responden membandingkan perilakunya dengan ajaran agama serta teman-temannya. Pada tahap identity comparison ini, jika seorang gay mendapatkan kontra dari msayarakat, teman, atau ajaran agama maka ia merasa berbeda denganorang lain atau bahkan dari temantemannya, oleh sebab itu seorang gay sebagian bedar masih berpura-pura sebagai seorang hiteroseksual (Mastuti et al., 2012).

Tahap yang ketiga yakni identity teleranc, responden melakukan toleransi dengan mencoba jujur akan keadanan dirinya, serta menerima yang ada dalam dirinya saat ini. Toleransi sendiri, berguna untuk meningkatkan komitmen sebagai seorang gay agar memiliki citra diri (Mastuti et al., 2012). Tahap yang ke empat yakni tahap identity acceptance, responden telah menerima dan bisa masuk kedalam komunitas-komunitas gay, serta ia sudah bisa lebih terbuka terhadap teman-teman dekatnya. Komunitas gay menjadi bagian yang penting dalam kehidupan gay karna dapat berfungsu dalam menjada rahasia dan juga sebagai pelindung. Dukungan sosial yang bersumber dari komunitas ini dapat memberikan informasi terkait hal apa yang harus dilakukan dalam hal upaya membentuk identitas dirinya, selain itu dapat pula memberikan timbal balik atas apa yang dilakukan dalam kelompok dan lingkungan sosialnya, serta mmberikan kesempatan untuk mencoba berbagai macam peran dalam menyelesaikan permasalahan guna membentuk identitas diri yang optimal (Mastuti et al., 2012).

Tahap ke empat yakni identity pride, responden sudah merasa bangga dengan keadaannya, hal ini bisa dilihat dari cara ia sudah bisa terbuka akan keadaannya kepada teman-teman dekatnya, tetapi disini 
Psikologia (Jurnal Psikologi), Vol 2 (2), July 2017 , 117 -134

ISSN 2338-8595 (print), ISSN 2541-2299 (online) Journal Homepage: http://ojs.umsida.ac.id/index.php/psikologia

DOI Link: 10.21070/psikologia.v3i1.1549

responden masih memperdulikan stigma sosial yang ada sehingga responden masih menjalani kehidupan dan hubungannya secara sembunyi-sembunyi. Pengungkapan diri pada tahap ini memiliki dua efek positif yakni yang pertama, menciptakan lebih banyak keterlibatan di komunitas sehingga mendapatkan dukungan diri sebagai seorang gay. Yang kedua yakni membawa identitas masyarakat ke dalam identitas pribadi (Mastuti et al., 2012). Tahap ke lima yakni identity synthesis, dimana responden saat ni memang sudah sepenuhnya menerima akan keadaan dirinya. Seseorang yang telah memasuki tahap ini maka dia telah memiliki kesadaran bahwa pandangan sebagai gay yang memiliki nilai negatif sudah tidak berlaku lagi (Mastuti et al., 2012).

\section{SIMPULAN}

Secara umum, dinamika yang terjadi pada responden sehingga dapat menyebabkan orientasi seksual mimiliki empat poin utama yakni, pola asuh orang tua, imitasi (modeling) terhadapt blue film, kekecewaan akan perempuan, serta lingkungan tempat tinggal yang mendukung perilaku responden. Dengan mengetahui hal tersebut, perlu kiranya diadakan penelitianpenelitian lanjutan dengan responden yang berbeda serta lebih luas bukan hanya pada kaum gay saja, guna mengetahui lebih bnyak dinamika orientasi seksual yang dialami oleh kaum LGBT.

\section{DAFTAR PUSTAKA}

Bandura, A. (1971). Social learning theory. Social Learning Theory. New York: General Learning Press. https://doi.org/10.1111/j.14602466.1978.tb01621.x

Creswell, J. W. (2014). Research Design. Yogyakarta: Pustaka Pelajar.

Glassman, W. ., \& Hadad, M. (2009). Approaches to Psychology (fifth edit). London: McGraw-Hill Education.

Gonsiorek, J. C. (2013). Introducing Psychology of Sexual Orientation and Gender Diversity. Psychology of Sexual Orientation and Gender Diversity, 1(1), 1-2. https://doi.org/10.1037/h0095935

Hayadi, F., \& Manna, A. K. (2017). Persepsi masyarakat tentang fenomena lgbt (lesbian, gay, biseksual, transgender) di kabupaten bengkulu selatan tahun 2016. Jurnal Ilmiah Multi Science Kesehatan, 14.

Hening, P., \& Fridari, I. G. A. D. (2014). Dinamika Kesetiaan Pada Kaum Gay, 1(2), 363-371.

Herdiansyah, H. (2015). Metodologi Penelitian Kualitatif untuk Ilmu Psikologi. Jakarta: Salemba Humanika.

Kendall, P. C \& Hammen, C. (1998). Abnormal Psychology. Boston: Houghton Mifflin Company. 
Mastuti, R. E., Winarno, R. D., \& Hastuti, L. W. (2012). Pembentukan Identitas Orientasi Seksual Pada Remaja Gay. Kajian Ilmiah Psikologi, 1(2), 194197. Retrieved from http://journal.unika.ac.id/index.php/pre/ article/view/271

Moleiro, C., \& Pinto, N. (2015). Sociodemographic and clinical characteristics of transsexual individuals who presented to a psychiatry clinic for sex reassignment surgery. Turk Psikiyatri Dergisi, 26(3), 153-160. https://doi.org/10.3389/fpsyg.2015.015 11

Ngun, T. C., \& Vilain, E. (2014). The biological basis of human sexual orientation: Is there a role for epigenetics? Advances in Genetics (Vol. 86). Elsevier. https://doi.org/10.1016/B978-0-12800222-3.00008-5

Patterson, C. J. (2000). Family relationships of lesbians and gay men. Journal of Marriage and Family, https://doi.org/10.1111/j.17413737.2000.01052.x

Yudiyanto. (2016). Fenomena lesbian, gay, biseksual dan transgender (LGBT) di Indonesia serta upaya pencegahannya. Nizham, 5(1).
Zakaria, M., \& Malek, N. A. A. (2014). Effects of human needs based on the integration of needs as stipulated in maqasid syariah and maslow's hierarchy of needs on zakah distribution efficiency of asnaf assistance business program. Jurnal Pengurusan, 40(June 2014), 41-52. https://doi.org/10.17576/pengurusan2014-40-04 